\title{
Context: The Role of Place and Heritage in Genealogy
}

\author{
Graeme Aplin
}

Citation: Aplin, Graeme. 2021. Context: The Role of Place and Heritage in Genealogy. Genealogy 5: 58. https://doi.org/10.3390/ genealogy5020058

Received: 13 April 2021

Accepted: 13 June 2021

Published: 16 June 2021

Publisher's Note: MDPI stays neutral with regard to jurisdictional claims in published maps and institutional affiliations.

Copyright: (C) 2021 by the author. Licensee MDPI, Basel, Switzerland. This article is an open access article distributed under the terms and conditions of the Creative Commons Attribution (CC BY) license (https:/ / creativecommons.org/licenses/by/ $4.0 /)$.
Independent Researcher, Wahroonga, NSW 2076, Australia; graemeaplin@optusnet.com.au

\begin{abstract}
Genealogical research often focuses to varying degrees on the family tree and the ancestors that inhabit it, often ignoring, or at least downplaying, broader issues. There is, however, much scope for broadening the research by adding leaves and flowers to the fruit (the people) on the tree. The broader context to a person's ancestry is often intriguing and enlightening, providing background information that places the people in their environments, perhaps explaining their actions and lifestyles in the process. Two aspects of this context are dealt with here. The first aspect relates to the place in which each person lives, in other words, to their geographical environment, both natural and social or human made. Secondly, their personal heritage is considered: this includes the most important items in their lives, perhaps inconsequential to others but with long-term meaning for them and quite possibly for their descendants. Other broader aspects of heritage may well be relevant, too.
\end{abstract}

Keywords: family history; context; environments; homelands; heritage

\section{Introduction}

Aplin $(2002$, p. 1) begins the Introduction to his book on heritage with the following passage:

We are all products of our personal and collective pasts, including those of our forebears and of local, ethnic, religious, and other groups to which we belong.

That, of course, also applies to our ancestors, those people on our family trees: their pasts are also, by extension, our pasts. Hence, finding out about all of those pasts is important in understanding our own past and present. However, as Jacobs states:

'Kids don't get inspired simply by learning the names, dates, and birthplaces of their ancestors. The key is the family narrative'. (Jacobs 2017, p. 50)

Two interrelated aspects of those pasts and of that narrative are the environments in which each person lived periods of their life, often termed their homeland(s), and what they saw as being the most important aspects of their heritage. Each of these two aspects will be treated separately, but remember, they are in a very real sense intertwined. However, important as they are, they will not help us understand the character of any individual fully, as the most personal aspects are not normally documented in the majority of the sources with which this paper deals, except perhaps in newspapers and the like, in military records, and, perhaps less fortunately, in court and hospital records. So, more traditional genealogical research is still crucially important, and the approaches suggested here are no replacement for it but an elaboration on it. Perhaps it is true to say, without being too negative, that:

Amateur local and family historians face a steep learning curve to analyse their data, view it in the framework of broader world and national history, and report their findings in ways that do justice to context. (Moore et al. 2021, p. 8)

While I am writing from an Australian cultural and family background, with my ancestors coming from the British Isles, the comments and suggestions that I make can be applied much more widely. Details of what is possible and what approaches need to be taken will, of course, differ from place to place. 


\section{Context for the Family Tree}

Family history researchers will often need to rely on living people's memories, so get in while those memories are intact and use what written evidence there is, such as letters or diaries, often kept very privately by still-living relatives. While 'studying family history usually begins with us talking to our nearest relatives, listening to their stories, piecing together the relationships, achievements, tragedies, triumphs and scandals' (Moore et al. 2021, p. 5), this need not be the end of the family history project. Those more personal aspects will become even more meaningful if seen in their environmental and heritage contexts.

Many genealogists and family-history researchers undoubtedly already do some, or indeed much, of what is suggested in the following sections. If so, they are down the road from a family tree to a family history or, if concentrating on an individual, to a historical biography. The latter two outcomes can be much richer than a basic family tree and more rewarding for the reader, as well as for the researcher and the study's living subjects.

The steps suggested in this paper will lead to a much more complete and informative outcome than would creating a bare family tree. If the people are the fruit on the tree, the contextual and circumstantial material alluded to in what follows can add the flowers and foliage. The matters in question can be broadly seen as environmental and heritage related. Environmental issues can be economic, social and political, as well as being related to the physical environment, the last including the built environment, whether rural or urban. All are part of a person's 'homeland', as is their heritage.

Family history is here seen to be set within the context of one or, probably, very many local, regional and even national histories. The extended genealogical or family history research outlined and advocated here will thus place the family members within a much broader context. It will hopefully be informative and even entertaining, while helping to explain relationships and outcomes along the branches of the family tree. The tree will, as a result, provide much more than merely a list of people and the bare relationships and lines of descent between them. It must be added, though, that what you learn about individuals may not always be positive or welcome news. Why, for example, was someone on my family tree banished from England to Rhodesia last century? Unfortunately, I do not know the answer. If I did know the answer, or that to any other possibly sensitive question, I would need to be extra careful in using it in my family history.

Of course, the geographical context and related heritage matters will be different for each person on the family tree, at least to a minor extent. The differences may become major as more distant branches of the tree are considered. As a result, the extra research needed to make these extensions could be very great and time consuming, but the outcomes may well be very rewarding and warrant that time and effort. In fact, with international migration and now (at least pre-COVID-19) such easy movement between places and cultural environments, any individual may have existed within a number of very different contexts at different stages in their life, and as compared to their close relatives. How far you extend your research is up to you, but you probably will not go as far as implied in the title of Jacobs' very readable book: It's All Relative: Adventures Up and Down the World's Family Tree (Jacobs 2017). As he states, we-all human beings, in fact-are all related if you extend the 'family tree' far enough, but what value of ' $n$ ' will you use to limit your tree to 'nth' cousins?

Some of the possible sources will be familiar to many people doing their family trees, but some will not be familiar to everyone. First and foremost, talk to surviving relatives, and even friends and acquaintances of the main characters focused on in this endeavour. Do this while you still have the opportunity, especially as related to older people, such as parents and grandparents. Ask them about places and relevant heritage features, as well as about the people as such. They will often be a fount of information that will help give context to the people on the family tree. What was their life like? Where did they live? Where did they meet? Did they move around, perhaps even migrating to a different country? If so, what was their new environment like for them? 
As made clear by Kyle (2011, p. 20): 'asking questions, critical questions, leads to the best kind of family story writing'. She also makes the point that photographs, maps and other illustrative material may also be invaluable (Kyle 2011, p. 20). These materials, along with words, may be available in the various sources dealt with in this paper. You may or may not feel comfortable, however, with Kyle's use of the terms 'easy' and 'very easy' in the titles of her very helpful books (Kyle 2007, 2011). Darby and Clough (2013) outline a model of the family history research process, in which stages increase in depth and difficulty. They also state that the steps may be repeated for each ancestral line.

Karskens notes a word of caution, pointing out that information on females on the family tree will frequently be harder to obtain than information on males, especially in the past (Karskens 2020, p. 17). If the place of residence or other association is known, this should not matter, as the same sources can be used as you would for a male. However, it may be more difficult to determine what place that was, especially for pre-marriage portions of a female's life. At the same time, as Karskens goes on to state in subsequent pages, historical writings and official records can tell you a lot about general attitudes to marriage and other relationships, such as the frequent marriage of older men to very young girls/women in early New South Wales (p. 332ff). As Jacobs puts it:

Even if we find the names of women from our past on various government documents, we often know little beyond that. Women are frequently ciphers, lacking stories, feelings, opinions. (Jacobs 2017, p. 232)

Similar comments can be made about ethnic and other minority groups. For example, it is very difficult to find information on many Australian Aboriginal people, especially those of the 'stolen generations' taken from their biological parents and placed in institutions or fostered by Europeans. The genealogist's task is made even more difficult by Aborigines not having surnames in the European sense until they became part of European Australian society. After a conversation with a former nurse at an Aboriginal mission, followed by a lot of help from Mr Google, I found a number of North Queensland Aboriginal people named 'Aplin', my surname. They had taken Aplin as their surname when they lived and worked on a large property owned by a great-uncle of mine. By contrast, there are very good records of the convicts transported to Australia in the late 18th and early 19th centuries: for a long time, Australians were loath to admit they had convict ancestors, even loath to try and find out if they did, but in recent decades having such ancestors has become almost a thing of great pride.

As will become very evident, if you are lucky, there is likely to be an enormous amount of material available to you, so this may be an appropriate place to quote Kyle (2011, pp. 21-22) once again:

[Writing] a family history is a unique process. However, it has at its heart a challenge familiar to most writers: how to rein in and shape a coherent story out of the overabundance of collected data now residing on our desks, in our computers and even under our beds!

All of the sources mentioned in the following sections may contain vital, or at least interesting, information. Just as importantly, however, they may well point you in the direction of other sources. Indeed, the total collection of sources may seem to you to be like a spider's web or a tangled mass of kelp fronds. Do not despair; untangling things can be fun, even if frequently frustrating, certainly time consuming. However, as Moore et al. (2021) state:

Standards of proof are important, and the dedicated genealogical researcher looks to 'triangulate' data, especially where there are ambiguities or inconsistencies in information collected. (p. 5)

Unfortunately, inconsistencies and ambiguities are all too common, particularly as much of the information is likely to be subjective, rather than objective. When you interpret the information and draw conclusions, another source of subjectivity enters the scene: this is inevitable, but care needs to be taken to be as objective as possible. 
One of the respondents in the research exercise of Moore et al. sums up the nature of family history as follows:

It is like working on a giant jigsaw puzzle and filling in small sections at a time. There are a few holes I dream of filling one day before I die. Each new piece gives me satisfaction. I am constantly amazed by the information which is available online ... Gradually, you can build up a picture of someone's life. (Quoted in Moore et al. 2021, p. 73)

\section{Sense of Place: The Environmental and Geographic Context}

Every person on any family tree will have lived, worked, played and travelled in particular places and environments, their 'homelands', to use current genealogical jargon. They will also have met each other, if that is relevant, in a particular place. They may have moved many times, or they may have stayed in the same place for all of their life, perhaps in the same place as their ancestors. Finding out even a little, and that may be all that is possible, about that place or those places will add to the understanding of the people involved. In some cases, knowing of a major move, even to a vastly different country through either voluntary or forced migration, will help understand the people and the lives they lived. There may, of course, have been dramatic changes between the period before the move and that after it.

Increasingly, genealogy studies will rely in part on DNA analyses. The results of these will often point to otherwise unknown and unanticipated branches on the family tree. At least in a broad national or regional sense, the results may open up connections with places not previously envisaged as relevant. They may also reveal unpleasant aspects of the person's ancestry, and privacy becomes of paramount importance here. Of course, individual ancestors and relatives are probably unlikely to be revealed, but at least environmental contexts and heritages are highlighted for investigation.

How does one find out about a particular place? In particular, how does one find out about a place at some time in the past? Lynch's book is titled What Time is This Place?: its main theme is summarised in the opening sentence of the dust-jacket blurb: 'In the personal image of a city the sense of place is meshed with the sense of time' (Lynch 1972). In an earlier work (Lynch 1960), he deals with how we conjure up images of places, specifically cities. The sense of place and the sense of time both involve the set of features that make a place recognisably different, easily identifiable and memorable (Aplin 1987). Together, they are the place's character at a particular time, summing up the nature and ethos of the place and leading to an accepted group or individual image of that place at that time. So, you will want to know what a place was like when the person on your family tree was there, when it was their 'homeland', and that certainly may not be what that place is like today.

If the places being investigated are in a nation or involve an ethnic group speaking a language other than your own, or other than one in which you are reasonably competent and comfortable, you will need assistance with translation. This applies to all of the potential sources mentioned in the following paragraphs. It will very likely also make communications with libraries and other officials more difficult. However, there is hope, as one respondent in the study of Moore et al. shows:

Because half of my family history has been in Europe-mostly in the Russian Empire of the 19th century, I have learnt to read handwritten birth, death and marriage certificates in Russian. I had studied some Russian before that, but not at a high level. This has been an enjoyable and rewarding challenge. (Quoted in Moore et al. 2021, p. 33)

I imagine this genealogist would also tackle the other sources referred to in this paper if they were in Russian, handwritten or printed.

If you are lucky, a local history of the relevant place will have been written. This may, or may not, be useful, however. Some local histories focus narrowly on the people who lived there, and your family-tree characters may or may not be featured. However, that local history may well not give much, if any, indication of what that place was like at 
various times. An example that I have seen is Weeks (2004), a local history of Lydford in the United Kingdom; it is strong on personalities but not so strong on the sense of place at various times. Alternatively, Karskens (2020) is a wonderfully detailed history of both the people and their environment on the Nepean-Hawkesbury River, west of Sydney in the late 18th century and the 19th century. Sometimes, there will be a well-researched work dealing with all the major places in a region, such as the wonderful volume on California (Abeloe 1966) or the 'Places' section in the Australian Bicentennial History volume Events and Places (Aplin et al. 1987). Of course, specific local histories or these broader collections may not cover all of the time periods relevant for your family tree or family history research. They need not, though, specifically mention the characters on your tree, as it is the environment and geographic context for each of them that is the key issue being addressed. Papers in journals such as this one will frequently be relevant, for example, Davies (2021) who uses the diary of an important ancestor as a key source. Online indexes are a key point of entry to such material. Academic theses are yet another potential resource, although possibly harder to find and use.

In some cases, town or city directories may be of assistance, even going as far back as the Domesday Book covering England and parts of Wales in 1086, now available online. As another more recent Australian example, many directories of Sydney published in the 19th century list occupants street by street, including both residences and businesses (for example, Low 1845). This might give an idea of not only the address of your person of interest, but also of the general nature of their surroundings and of the broad type of people who were their neighbours. Censuses may also give an indication of the broader population characteristics of a particular town or rural area.

At least a general overview of a country or region can be gained from reading geographic and historic works and even travel guides, such as the DK Eyewitness Travel series or the Lonely Planet series. Depending on the places of interest to you, you may gain much more from such works, especially if those places are better known and more important. As with any of the sources mentioned in this paper, the most rewarding aspect of these general works is that they may well point you in the direction of further research and to more specific resources.

Being the 21st century, one cannot ignore Wikipedia and search engines such as Google. Relevant local history, genealogical and community groups often have pages on Facebook and the like, too. Wikipedia has entries on surprisingly small and unimportant places, as well as on larger towns, cities, regions and countries. Most Wikipedia entries are frequently being checked, corrected and added to, though this may be less likely for smaller centres. There will also be entries on people and local institutions. By and large, this source is reliable, though checking against other sources is always a good idea, if possible. The same is true for the other sources already mentioned and those that follow, particularly as they have often relied on personal memories, and these are not always reliable.

Google and other search engines can lead you to the official sites of local government bodies, and these frequently include a reasonably sized section on local geography and history. Other bodies, both volunteer-based ones, such as historical societies, and more official ones, such as business groups, farming organisations, military units and educational institutions, are all likely to have websites that can be checked for relevant content. So, too, can religious, sporting, arts and leisure-oriented organisations.

Local and broader scale newspapers and magazines may also be useful, especially if they have been included in library collections, which makes them more accessible, and, hopefully, they will have been indexed. In Australia, we are lucky to have Trove, the website of the National Library of Australia, which makes it possible to easily search all the newspapers in their collection, many surprisingly small and local ones, as well as books and academic papers and theses. If you do use Trove or an equivalent, or look into the collection in any other library or archives, you might need to actually go there and use the material on the spot. Some items listed on Trove, for example, are available online, but far from all of them are, and physical borrowing of material is unlikely to be possible if a 
distant library is involved. Two other advantages of a library visit are that you might gain ideas for other sources by browsing the shelves and that the staff will almost invariably be of great assistance.

Finally, if at all possible, visit the places of interest that have connections to people on your family tree. Basu (2005) writes of the ways that a new form of travel referred to as 'genealogical tourism' can contribute to developing a sense of place, the place in which your ancestors once lived. When it comes to a distant past, visiting the place of origin might provide insight into such matters as the difficulties of farming or the remoteness of village life. A visit will be particularly rewarding if a large number of your tree-family relate to the one place, less so if they have been widely scattered over many places. You should be able to get a feel for the environment and heritage (next section) of a place. Most valuably, you may be able to speak with people with a knowledge of your ancestors and relatives. Struckland (2018), for example, writes of his urge to visit Norway to follow up on some of his Norwegian ancestors. In his case, these ancestors came to the USA as migrants. Many people in that country, and in others such as Australia and Canada, for example, have migrant forebears and can profit greatly by following up on the homelands of these people, possibly visiting their places of origin, as Struckman did. Two papers by or involving Solène Prince also deal well with genealogical or ancestral tourism: Prince (2021) and Mehtiyeva and Prince (2020). The Journal of Heritage Tourism is also a possible source more broadly and is particularly relevant to the following section.

It is important to remember that it will not be present conditions that are of interest, but conditions at times relevant to the lives of people on your family tree. Many Australians came to their new country from war-torn Europe or conflicts in Southeast Asia, the Middle East or Africa, at least in the days of Australian governments being more sympathetic to refugees. Friends of mine with Hungarian or Czech family backgrounds, for example, have commented to me on how great the changes have been since they left, or from what their parents and grandparents have spoken about.

Archaeological work might also be very relevant, though not necessarily that involving ancient sites. Archaeologists have, in recent decades, realised increasingly that their work can assist our understanding of historic times, perhaps quite recent ones. A friend of mine was reminded of a recent archaeological dig in Tasmania, where they uncovered artefacts from the convict road station set up when convicts were building the Heritage Highway. This was of interest to her because her convict ancestor was in a road gang building this highway and at one point was given 35 lashes for sitting down on the job. She is going to visit this dig spot next time she goes to Tasmania. Purely by coincidence, a 19th-century ancestor of my wife was also a convict in the same general area, very likely at the same time, and we found out on a visit to the most relevant town in Tasmania that his sentence was truncated, and he became a police officer supervising later convicts. I need to liaise with my friend and look for connections. This is the kind of outcome from site visits and local records that can add significantly to a family history.

\section{Heritage}

'Heritage' can have many meanings. One interpretation of a person's heritage relates to their cultural background and is both wide reaching and akin to their homeland or certain of the kinds of environmental contexts referred to in the previous section. Another interpretation, and the one used for the following section, relates to particular sites (and sights) and individual objects that are important to the person with whom you are concerned. These personal heritage items may be included in the broader heritage, or they may not. For example, family historians may view as part of their personal heritage the towns, farming areas and even houses where their ancestors lived, the churches where they married and the high streets where they shopped. One described to me the sense of excitement she felt in locating the Powis castle estate in Wales where her fourth greatgrandfather had run the flour mill, the town of Westbury in Wiltshire where her second great-grandfather stole 12 rounds of cheese (and was transported to Van Diemen's Land) 
and the St Michael and All Angels' Church in Haworth where several of her ancestors were baptised by the Reverend Patrick Bronte, father of the Bronte sisters.

In recent decades, heritage in a societal context has become much more important in public debate, and governments at all levels in many nations have legislated to protect at least some key elements of it. Heritage occurs on all scales from the global World Heritage List, through national, state (or equivalent) and local government levels to the very local and even personal levels. However, heritage in the broader sense goes far beyond what is inscribed on official lists. A person's heritage reflects their homelands at various periods in their life, hence the strong link with the previous section, but also their cultural background and also their individuality and personality. As with homelands, it is the heritage of the relevant time for each person that needs to be researched, and this may be very difficult to do in terms of a lack of evidence of earlier views of heritage, or those of different countries.

The official registers concentrate on heritage sites that are considered important under agreed criteria concerning natural environments, cultural or built environments or a mixture of the two. Items are placed on the lists because they are deemed to be of importance under those criteria, and at the relevant scale, for present and future populations. There is often a historical element in the reasons for inscription, but not necessarily so. Obviously, not everyone in the relevant cohort will agree on the decision to list; after all, we all have different views on our environments and the objects within them. Once listed, heritage items are given legal protection from changes that detract from their listing criteria, although there are frequently loopholes that do allow change and development, even elimination.

Particular items of natural heritage relevant here might be a coastal area where your person of interest surfed, a national park where they bushwalked or studied the wildlife, a river where they fished or a view they adored. In the cultural heritage field, various sites and individual buildings might be important: where your subject went to school, worshipped, holidayed or met their partner might be especially meaningful to them. There are an almost infinite number of reasons why a place or object might be of great importance to any individual.

There are also some official lists referring to intangible and moveable heritage items and these are the objects likely to be cared for in museums and libraries. Also included in some cases are folk dances and music, other social events, belief systems, endangered languages and on and on it goes. Perhaps the most notable intangible heritage lists are the UNESCO Memory of the World Register (UNESCO 2012) and the list for the Convention for the Safeguarding of the Intangible Cultural Heritage. Sometimes items on these and similar lists will have a clear relationship with a place, frequently with a nation or region. The included items may well have importance for people on your family tree. We have already mentioned libraries, but local museums, especially history museums, may also give assistance in finding what is/was of personal importance to people on your family tree. More generally, historical museums will very likely give important pointers to what the local area was like at various times in the past, thus linking us back to the previous section of this paper.

In fact, the definition of what constitutes 'heritage' is an individual, subjective matter depending on a person's background, life experience and personality, although groups of people, perhaps defined on a socio-economic, cultural or ethnic basis, may share many aspects of their perceptions. In similar fashion, the definition of 'heritage' in any particular country depends on local historical, social and cultural circumstances. Within any nation, the 'official' or 'accepted' definition is frequently that of some dominant group. In other words, the concept of 'heritage' is appropriated by that group as one more manifestation of its dominance in politics and national debate. Some 'ownership' of at least part of the officially recognised heritage of a country is important to many groups to help manufacture and maintain their group identity, for example, indigenous peoples, migrant groups, religious denominations and local communities. One example is the difficulty the Basque population in Spain is having in getting its heritage recognised at the national level or, even more pointedly, the troubles the Rohingya people have in Myanmar. Fernández (2020) 
touches on the need for migrants to the US from Galicia (another minority population in Spain) and their descendants to establish and maintain ties with their ancestral homeland and to understand their heritage. She deals with the value of visits to that homeland, something raised earlier in this paper. Closer to my home, the heritage of the Australian Aboriginal and Torres Strait Islander peoples is finally being increasingly recognised as being a crucial element in our national heritage. It is absolutely crucial to people in those groups and would be an essential part of any family history involving them.

An individual featuring on a family tree or in a family history will have their own bundle of heritage items important to them, even if not always to anyone else. Often, some very personal item or experience will feature front and centre in a person's understanding of their heritage. This could be a childhood toy, such as a bunny, a child's blanket or an early item of clothing, things that seem trivial to anyone else. It might be a pet cat or dog, a favourite holiday location, a school or sporting centre or, later in life, a favourite car. Such items could be unique to the individual and help define who they were and what their personality was like. As such, they may add important information on the life of the person(s) concerned and thus increase the value of your family tree.

One can then look at increasingly broad areas and the heritage items involved in those expanding spheres. It is important to be aware of the fact that an individual's understanding of the importance of heritage items may well be quite different from the official bodies' views. A person may have seen something that escaped the official list as being of crucial importance for them, while they may also think that a listed item is unimportant. In the present context, an individual's view of heritage is important, not that of some government body. Again, sources beyond the official ones might well be central to understanding what heritage items mattered to the person on your family tree, and, preferably, why they mattered. It is also crucial to remember that heritage from a cultural background very different from that of a person's present location may be most important. As an example, British settlers in Australia brought a vast amount of British heritage with them, including placenames, food and customs. They even imported plants, animals and birds to remind them of 'home'. Some of these plants and animals subsequently became detested pests in their new home. More recent immigrant communities in Australia have also retained many features of the culture and heritage of their countries of origin, greatly enriching Australian life as a result.

As stated above, any significant concern with heritage, at least officially, is quite recent, basically increasing from the early 19th century in voluntary bodies, such as the National Trusts in various nations, then being taken up by governments at all levels. The success of these listing processes is very variable. The point here, however, is that there were not usually equivalent heritage lists in earlier times, so other sources will probably need to be used. The same items as are now on the lists, as well as others that have been demolished or irrevocably altered since the time of interest to you, could be the very ones that mattered most to the person you are wanting to study. As well as that, people's views on what are and are not important items have changed over time. Some of the sources treated earlier under the 'Environment' section are also key for heritage.

One type of heritage listing that may be particularly relevant in the family history and genealogy context is the World Heritage Committee's category of 'Cultural Landscape', first used officially by that body in 1987 (Aplin 2007, pp. 427-28). Such listings, beginning in 1992, involve a marriage between physical landscapes and human occupation and alteration of them. Compared to most World Heritage sites, Cultural Landscapes are broader, both spatially and conceptually. According to the World Heritage Committee (WHC):

There exist(s) a great variety of landscapes that are representative of the different regions of the world. Combined works of nature and humankind, they express a long and intimate relationship between peoples and their natural environment. ... To reveal and sustain the great diversity of interactions between humans and their environment, to protect living traditional cultures and preserve traces of 
those which have disappeared, these sites ... have been inscribed on the World Heritage List. (WHC 2004; Aplin 2007, p. 430)

In many ways, a Cultural Landscape can be seen as analogous to the genealogist's 'homeland'. All examples inscribed on the World Heritage List have full descriptions and justifications available at the WHC website, whc.unesco.org (accessed on 15 June 2021). The WHC website currently (April 2021) lists 115 inscribed Cultural Landscapes, as well as giving much information on the concept, and on the criteria and processes involved in listing (WHC 2021). Some sites are basically agricultural regions, while many others are much harder to categorise, being 'various mixtures of architecture, sacred or religious sites, traditional land use, and spiritually important landscapes' (Aplin 2007, pp. 436-37). Yet, others relate to routes of cultural importance.

If your homeland of interest happens to be located in one of these inscribed sites, you are very fortunate and can use the information provided. If it does not, then these examples provide a template for what you might do, presumably on a smaller scale, to write up a description of your homeland of interest.

\section{Conclusions}

As Karskens notes: 'Any historical approach that ignores human emotions will fail to see the forces that compelled people's movements, interactions, strategies and behaviours' (Karskens 2020, p. 326). She goes on to stress that lives in the past were often less than smooth going. The approaches I suggest in this paper are, in a sense, taking things the other way around. The 'forces' Karskens refers to are to a large degree encapsulated in a person's environment and their heritage. Knowledge of these aspects will help understand both the 'movements, interactions, strategies and behaviours' and perhaps extend an understanding of the subject's personality and emotions. However, these more abstract aspects of a person's life in the past are bound to need some more personal source of information to be fully understood in relation to that personality and those emotions.

The aim of the approaches and use of sources dealt with above is to add spice to your family tree, to make it much more than simply a visual representation of family relationships across the decades and centuries. Instead of the bare branches with a few names on them, you can have something more like a highly decorated Christmas tree. Assuming you have a family tree that goes back a considerable period of time and extends to more distant relationships, perhaps including people living in different 'homelands', there will be a great deal of work involved in turning the family tree into a family history. It will be very rewarding, though, and an excellent hobby to keep the mind sharp, as well as something of great value to share with other family members and to leave for future generations, who will, hopefully, add to it as time goes by. As Australian feminist Anne Summers says of her family history endeavour:

I loved the moment of triumph whenever a sliver of information fell into place, when I cracked the challenge of a library catalogue or when I made the connection between two seemingly unrelated events. (Summers 2009, p. 42) Moreover, you may even be able to add some entertainment value: when the author sourced his father's Australian Army records, he found the entry 'Son born' (me), and the pencilled query someone had added 'Married?'. My father had omitted to tell the Army that he married my mother on his previous home leave, almost exactly nine months previously.

Funding: This research received no external funding.

Institutional Review Board Statement: Not applicable.

Informed Consent Statement: Not applicable.

Conflicts of Interest: The author declares no conflict of interest. 


\section{References}

Abeloe, W. N. 1966. Historic Spots in California, rev. 3rd ed. Edited by M. B. Hoover, H. E. Rensch and E. G. Rensch. Stanford: Stanford University Press.

Aplin, G. 2002. Heritage: Identification, Conservation, and Management. Melbourne: Oxford University Press.

Aplin, G. 2007. World Heritage Cutural Landscapes. International Journal of Heritge Studies 13: 427-46. [CrossRef]

Aplin, G. J. 1987. Sense of time, sense of place. Paper presented at Conference of the Sydney History Group, Sydney, Australia.

Aplin, G., S. G. Foster, and M. McKernan, eds. 1987. Australians: Events and Places. Sydney: Fairfax, Syme \& Weldon Associates.

Basu, P. 2005. Macpherson Country: Genealogical identities, spatial histories and the Scottish diasporic clanscape. Cultural Geographies 12: 123-50. [CrossRef]

Darby, P., and P. Clough. 2013. Investigating the information-seeking behaviour of genealogists and family historians. Journal of Information Science 39: 73-84. [CrossRef]

Davies, B. 2021. Re-turning to the event of colonisation in New South Wales. Genealogy 5: 2. [CrossRef]

Fernández, N. 2020. Constructing National Identity Through Galician Homeland Tourism. Genealogy 4: 1. [CrossRef]

Jacobs, A. J. 2017. It's All Relative: Adventures Up and Down the World's Family Tree. London: Oneworld Publications.

Karskens, G. 2020. People of the River: Lost Worlds of Early Australia. Sydney: Allen \& Unwin.

Kyle, N. 2007. Writing Family History Made Very Easy: A Beginner's Guide. Sydney: Allen \& Unwin.

Kyle, N. 2011. How to Write and Publish Your Family History in 10 Easy Steps. Sydney: New South Publishing.

Low, F. 1845. The City of Sydney Directory for 1844-5. Sydney: Facsimile reprint by the Library of Australian History.

Lynch, K. 1960. The Image of the City. Cambridge: MIT Press.

Lynch, K. 1972. What Time Is This Place? Cambridge: MIT Press.

Mehtiyeva, A., and S. Prince. 2020. Journeys of research, emotions and belonging: An exploratory analysis of the motivations and experience of ancestral tourists. Scandinavian Journal of Hospitality and Tourism 20: 85-103. [CrossRef]

Moore, S., D. Rosenthal, and R. Robinson. 2021. The Psychology of Family History: Exploring Our Genealogy. Abingdon: Routledge.

Prince, S. 2021. Affect and performance in ancestral tourism: Stories of everyday life, personal heritage, and the family. Journal of Heritage Tourism. Available online: https:/ / www.tandfonline.com/doi/full/10.1080/1743873X.2021.1883033 (accessed on 12 February 2021). [CrossRef]

Struckland, R. 2018. A U.S. traveler's urge to see Norway is all in his genes: As genealogy rises in popularity, more tourists are being inspired to explore their ancestral homelands. The Washington Post, September 20.

Summers, A. 2009. The Lost Mother; Melbourne: Melbourne University Press. Available online: www.trove.nla.gov.au (accessed on 15 June 2021).

UNESCO. 2012. Memory of the World. Paris: UNESCO Publishing; Glasgow: Harper Collins.

Weeks, B. 2004. The Book of Lydford, an Saxon Borough. Tiverton: Halsgrove.

WHC (World Heritage Committee). 2004. Cultural Landscapes. Available online: whc.unesco.org (accessed on 11 June 2021).

WHC (World Heritage Committee). 2021. 'Cultural Landscapes', Available from the WHC Website under 'Activities' and then 'Cultural Landscapes'. Available online: whc.unesco.org (accessed on 11 June 2021). 